\title{
Introduction of Special Issue "Religion and Refugee: Interdisciplinary Discussions on Transformative Human-Divine Interactions"
}

\author{
Alexander Horstmann ${ }^{1, *}$ and Jin-Heon Jung ${ }^{2, *}$ \\ 1 School for Humanities, Tallinn University, 10120 Tallinn, Estonia \\ 2 National Institute for Unification Education, Seoul 01018, Korea \\ * Correspondence: alexander.horstmann@tlu.ee (A.H.); poem04@unikorea.go.kr (J.-H.J.)
}

Citation: Horstmann, Alexander, and Jin-Heon Jung. 2021. Introduction of Special Issue "Religion and Refugee: Interdisciplinary Discussions on Transformative Human-Divine Interactions". Religions 12: 202 https://doi.org/10.3390/rel12030202

Received: 26 January 2021

Accepted: 8 March 2021

Published: 18 March 2021

Publisher's Note: MDPI stays neutral with regard to jurisdictional claims in published maps and institutional affiliations.

Copyright: (C) 2021 by the authors Licensee MDPI, Basel, Switzerland. This article is an open access article distributed under the terms and conditions of the Creative Commons Attribution (CC BY) license (https:// creativecommons.org/licenses/by/ $4.0 /)$.
Mainstream works on refugees and religion have underlined the value that religion provides to émigrés. In his classical work on Catholic Sicilians in Brooklyn, Orsi gives an intimate portrait of the Southern Italian diaspora for whom Catholicism is a marker of their cultural identity and pride and a vehicle of place-making and homemaking in America, but also of boundary-making to other settler communities (Orsi 2010). Following Orsi's footsteps, Tweed develops a complete theory of religion as both a medium that is central to crossing boundaries and to dwelling. In this Special Issue, we endorse Tweed's idea of migration as a theologizing experience that is both cross-spatial and cross-temporal (Tweed 2008). Joining Tweed's emphasizing of the orientational and emotional qualities of religion, we argue that religion is a transformative force, being performed with joy and assertion: The original statue of the Lady of Charity helps Cuban Catholics in Miami to remember their painful pasts and to reconstruct their futures (Tweed 2002). In this, she resembles our Lady of Lavang, so cherished by the American Vietnamese diaspora in Southern California (Ninh, this issue). In this sense, religion serves indeed as a compass, keeping people afloat in stormy waters and helping to heal open traumata.

However, while religion offers sanctuary and empowers the most vulnerable groups, religion is also used to create boundaries, alternate political discourses, parallel societies, or to produce communities and cells of utopian thinking and for the circulation of political ideologies. This Special Issue recognizes the forceful impact that religious nationalism has on society or radicalized parts of society but prioritizes expressions of religion in transnational and global fields. More specifically, our authors explore the tensions and power negotiations that emerge with the place of religion in the political realm and humandivine interactions.

With little doubt, World War II's aftermath is most significant since the refugee definition came to be institutionalized through the United Nations' formation. Subsequently, the world became polarized between the capitalist and the socialist, and some regions underwent post-colonial transformations. This period characterizes the Cold War when proxy wars never stop on earth. For decades, refugees and migrants were likely framed in secular terms; the latter was mainly considered a flux of individuals from the third world countries to the advanced for economic purposes, while the former was framed primarily in political terms.

As Keely (2001) observes, the asylum seekers from the socialist countries were selectively and officially welcomed as a symbol of the liberal superiority over the socialist, so were the other way around. Religion in this ideological battle appeared to support the liberal states. Mainstream faiths, including Christianity, Muslim, Buddhism, Hinduism, and indigenous ones, often collaborated as the liberal capitalist systems' bulwarks against socialism. One example is a mosque established in 1976 in Seoul, South Korea. It was a governmental project to which diverse Muslim countries, regardless of their denominational differences and internal conflicts, contributed financially to the name of anti-communism 
(Song 2016). Likewise, most religions served as, what Jose Casanova calls, public religions, signifying the religious institutions' political and social engagements in public spheres, rather than remaining in the private realms (Casanova 2003).

Yet, it is fair to say that religion stayed as auxiliary to nation-states in the refugee regime. Domestically, religious organizations challenged, negotiated, or collaborated with the state governments for the political, social, and moral issues. Internationally they continued evangelical or ecumenical movements beyond national borders. Not to mention the humanitarian aid works for the refugees and migrants in need. In a sense, religion was likely unseen since the Big Powers' political, ideological, and economic races until the collapse of the Soviet Union following the Berlin Wall fall. When the Cold War competition ended, the world seemed to end antagonistic conflicts as well. Among the seven or eight civilizations in his hypothesis, Huntington (1993) exceptionally pinpoints the more significant division and conflicts between Islam and the West. In other words, religion, as a representative of the culture, appeared to surpass the primary secular concerns. Additionally, Huntington's view seemed to be proved by the devasting 9.11 attack followed by a series of wars on terrorism. However, as Said (2001) has succinctly criticized, such perspective oversimplified and ignored each civilization's internal diversities and dynamics, and interrelation and interactions among the diverse cultures. Moreover, Said highlights the fact that "the basic paradigm of West versus the rest (the cold war opposition reformulated) remained untouched" (Said 2001). This critique suggests we acknowledge that the paradigm tends to shed light on an evil role of religion, particularly Islam confronting the West. An underlined perception in the international refugee regime is not different from this simplistic and controversial view either.

In this sense, this Special Issue attempts to drive our attention to more multifaceted, complicated, transformative, dynamic, and aspirational aspects and roles that diverse religions play and serve for the refugee individuals. Religion is here not abstract, but a real force and mind that live and travel together with the believers, who negotiate and aspire to a better world by not dividing but rather transcending the lines and boundaries. Accordingly, our essays may contest the basic paradigm, which still tends to divide the world into two binary extremes. Refugee-migrants, our interlocutors, exhibit that the national, ethnic, and human-divine borders are porous and negotiable in their religious rituals and terms, which in turn empower them to make their place and home in a new world.

Islam has taken a big space in much of the political debate on refugees and religion and the fear that Muslim refugees from Syria, Afghanistan and Iraq, Chechenia and Bosnia import a radicalized version of Islam to Europe (Mavelli and Wilson 2017). This Special Issue rejects easy simplifications, but explores the encounters of, spaces in-between, and negotiations of religion in the context of diaspora. We explore the impact of migrant churches and transnational communities and movements and how these religious actors use religion to make meaning and sense of their own worlds and their place within strange, and sometimes hostile environments. We hence examine the tensions emerging between the evocation and revitalization of religion and its central importance to cultural identity, its central importance to memory and its spiritual, but also, not less meaningful, material manifestations, with the self-understanding of Western European societies as firmly secular. For this purpose, we have invited a fascinating collection of stories that showcase case-studies not only of travelling religion, but also the power configuration that religion assumes and the multiple strategies that religion is not only used as spiritual or cultural phenomenon, but as a very political vehicle that is not only materialized as churches, mosques, temples or monasteries, but also as institutional structures, investing into parliaments, infrastructure, into communication, education, and finances.

Our authors study missionization, diaspora and travel from a global perspective, overcoming a purely ethnocentric perspective that would see the center of missionizing activities in the global North. Based on regional expertise, our authors show the multiple origins and directions that religious empires can take. Our authors also reject a perspective that regards refugees or religious minorities as passive recipients of humanitarian aid- but 
showcase the way that religion transforms refugees into active subjects who creatively use religion to form movements that span the globe.

Jung describes the passages of two North Korean men from North Korea to the secret Christian shelter in Northeast China, and on to South Korea. Yet, for many North Korean migrants, the journey does not end in South Korea. Fearful of discrimination in South Korea, many North Korean refugees travel on to Europe in hope of refugee status and a better life for themselves and for their children. For both interlocutors, Christianity played a growing role in their acculturation processes and helped them to see their migration as God's will. The paper speaks to Tweed's theory of regarding migration as a theologizing experience.

Horstmann documents the encounter of a Christian humanitarian organization with a vulnerable ethnic minority in the mountains of Eastern Myanmar. The American leader and his team stand with the displaced Karen, help the wounded, and invite them to join his Kingdom of God. The Free Burma Rangers has established itself in all ethnic minority regions of Myanmar, joining the armed ethnic resistance movements. The Rangers, coming from a variety of ethnic minorities and religious traditions, convert in two ways: They not only convert to Christianity, but also to the modernity of modern humanitarianism and to modern warfare. Moreover, the most rusted Karen Rangers have become missionaries and humanitarians, travelling as far as to places in Iraq and Syria. In a way, the Karen Rangers were becoming integrated in an American masterplan to save the world from evil. As in Jung's article, religious expression here goes hand in hand with humanitarian patrimonialism.

Dumovich's interesting article is concerned with the Islamic Gülen movement, the largest Turkish global movement. The movement has set up 1000 educational institutions around the globe to promote Gülen's educational model, spanning 140 countries. However, the Gülen movement in Turkey was persecuted severely, its members and sympathizers have been arrested or emigrated and its assets taken. Gülen's ideological thinking promotes the dialectics of hicret and hizmet. Hicret means outer migration, renunciation of material life and total submission to God in the Sufistic sense. Hizmet means sacrifice and religious service. The global expansion of the movement saved it in the time of purge. Travel as hicret then becomes a theologizing, sacralized experience, emulating the prophet's emigration from Mecca to Medina in 622 CE. Dumovich's account is based on the presence of the Gülen movement in Brazil. More than 20 families fled from persecution in Turkey to Brezil. Dumovich's interlocutors believe that service means self-development and global development of the world.

In her rich portrayal of Coptic's concept of love, van Raemdonck argues that Copts draw strength against discrimination from their unlimited universalization and endorsement of love. The Coptic community in Egypt is a minority that shares a strong cultural consciousness, a theology of persecution and martyrdom. The response is love rather than hate. While- according to her interlocutors- love in other religion is limited to members of the same religion, the Copt minority in Cairo equals love with God and unlimited faith, which allows the Christian Copts to love their enemy. As they achieve loving their enemy, they overcome the discrimination to which they are subjected in urban Cairo. As loving people- against all odds- the Christian Copts regard themselves as the chosen, characterized by civilization and unbounded faith. Van Raemdonck shows how the study of the everyday enlighten us on the normative and the lived way that religion is understood without leaving the important subject of love and loving to the philosophers.

Ninh is-like Orsi and Tweed before-concerned with a diaspora in the US, namely the Vietnamese diaspora in Southern California. Even though the diasporic communities hail from two different strands of Vietnamese religions-Catholicism and Caodaism-Ninh argues that they strongly identify with the same Mother Goddess, "Lady of Lavang". However, the miraculous appearance of the image of the Lady of Lavang is also an appropriation: The Lady of Lavang becomes a Vietnamese woman that leads the Vietnamese diaspora in stormy waters and protects them. In this sense, the Lady of Lavang and her 
miraculous appearances heal the diaspora from painful pasts and offers blessings, comfort, and guidance on their travel. "Our Lady of Avang" becomes a massive icon for identification and her shrine becomes the spiritual center for the global Vietnamese diaspora scattered around the globe. While Mother Goddess rituals are forbidden in Communist Vietnam and must be secretly performed, the Vietnamese diaspora in the US and beyond puts together resources to build a big and expensive shrine for the Mother Goddess "Our Lady of Lavang".

Tobin's article returns to the use of religion for boundary-making in a diaspora situation. Using a vernacular politics perspective, Tobin argues that the sectarian discourses and localized histories of Syrian refugees have the potential to introduce new forms of divisiveness in Jordanian society. Based on ethnographic research and participation in female Islamic classes in a Syrian refugee camp, Tobin argues that the danger of new forms of divisions prompt Jordanians to assert that Jordan is free of divisions and will remain so in the future. Tobin reveals that Jordanian female teachers use a discourse that sectarian discourses are un-Islamic or heretical. The presence of Syrian refugees thus has the potential to cause tensions between Muslim sisters and brothers.

In the Quaker (Religious Society of Friends) sanctuary tradition, Rabben follows her extensive work on the Christian sanctuary movement in the US. She shows that the Quakers have a long tradition to offer sanctuary to refugees. She shows that the Quaker tradition to offer sanctuary to persecuted people goes back to the time of slavery, in which the progressive wing of the Quakers organized an underground railway for runaway slaves. Quakers also were highly active in organizing the Kindertransport to save 10,000 Jewish children from Germany, Austria, and Czechoslovakia from the Nazis. Quakers were also the founders of the 1980 sanctuary movement that protested American support of dictators and offered a safe place for refugees, offering help and protection without making a difference between documented and undocumented migrants. The Quakers have been themselves persecuted in the beginning and from this experience they have decided to provide sanctuary for the most vulnerable. Rabben's work on the sanctuary movement is highly topical in a world where there is an increase of refugees fleeing political persecution and populist governments that introduce increasingly restrictive legislation against refugees.

Buber-Ennser and colleagues examine the religious composition and religious activities of refugees entering Austria between 2015 and 2017. Buber-Emser et al. give a concise overview of the composition and argue that while religion has played a substantial role for the first steps of integration and support structures, there are different levels of religiosity and secularization. In conclusion, the article provides valuable survey data on the role of religion during displacement and settlement in Austria.

The contributions to this Special Issue provide highly valuable and carefully researched accounts of the role of religion in the context of forced migration. The contributors describe refugees as acting subjects, for whom religion is deeply embedded in their dreams, utopias, and healing. Furthermore, the contributors show how crucial religion is for the networks and place-making strategies of refugees and how inherent religion is to travel and emigration. Religion is equally important as a boundary and identity marker, and has a strong material side. The material side does not only concern the religious objects that refugees keep for spiritual comfort and protection, but also the institutional structures that refugees build in exile. In summary, this Special Issue makes an important contribution to the field of religion and refugees.

Conflicts of Interest: The authors declare no conflict of interest.

\section{References}

Casanova, José. 2003. What is a public religion? In Religion Returns to the Public Square: Faith and Policy in America. Edited by Hugh Heclo and Wilfred M. McClay. Washington, DC: Woodrow Wilson Center Press, pp. 111-39.

Huntington, Samuel. 1993. The Clash of Civilizations? Foreign Affairs 72: 22-49. [CrossRef] 
Keely, Charles B. 2001. The International Refugee Regime(s): The End of the Cold War Matters. The International Migration Review 35: 303-14. [CrossRef]

Mavelli, Luca, and Erin K. Wilson, eds. 2017. The Refugee Crisis and Religion: Secularism, Security, and Hospitality in Question. London: Rowman, New York: Littlefield.

Orsi, Robert A. 2010. The Madonna of 115th Street: Faith and Community in Italian Harlem, 1880-1950. New Haven and London: Yale University Press.

Said, Edward W. 2001. The Clash of Ignorance. Nations. October 4. Available online: https://www.thenation.com/article/archive/ clash-ignorance/ (accessed on 1 January 2021).

Song, Doyoung. 2016. "Ummah" in Seoul: The Creating of Symbolic Spaces in the Islamic Central Masjid of Seoul. Journal of Korean Religions 7: 37-68. [CrossRef]

Tweed, Thomas. 2002. Our Lady of the Exile: Diasporic Religion at a Cuban Catholic Shrine in Miami. Oxford: Oxford University Press.

Tweed, Thomas. 2008. Crossing and Dwelling. A Theory of Religion. Cambridge: Harvard University Press. 